\title{
Ultraviolet radiation and aerosol monitoring at Lampedusa, Italy
}

\author{
Daniela Meloni (*), Franco Marenco and Alcide di Sarra \\ ENEA, CLIM-OSS, Centro Ricerche della Casaccia, S. Maria di Galeria (Roma), Italy
}

\begin{abstract}
The measurements of UV spectral irradiance, ozone and aerosol load obtained with a double monochromator Brewer at the Station for Climate Observations of the National Agency for New Technology, Energy and Environment (ENEA) in Lampedusa, Italy, are presented. To derive the aerosol optical depth, the direct-sun measurements at the Brewer operational wavelengths (302.1, 306.3, 310.1, 313.5, 316.8 and $320.1 \mathrm{~nm}$ ) were calibrated using the Langley method. A radiative transfer model was used to investigate the role of ozone and aerosols in modulating UV irradiance and to reproduce the measured UV spectra. The optical scattering and absorption properties of aerosols input to the model have been derived from measured size-distributions. The modelled and measured UV spectra are in agreement for different atmospheric conditions and allowed us to estimate the radiative impact of the aerosols for two case studies related to the PAUR II campaign held in 1999.
\end{abstract}

Key words UV radiation-aerosol-ozone-radiative transfer - radiative forcing

\section{Introduction}

The amount of solar radiation reaching the Earth in the UV spectral region is affected by several factors such as solar zenith angle, ozone, cloud cover, aerosols and surface albedo. The observed decrease of stratospheric ozone (Harris et al., 1997) at high latitudes and, to a lesser extent, at mid-latitudes is expected to lead to an increase in UVB levels at the surface (Madronich, 1992), with potentially harmful effects to marine ecosystems, terrestrial vegetation and humans

Mailing address: Dr. Daniela Meloni, ENEA, CLIMOSS, Centro Ricerche della Casaccia, Via Anguillarese 301, 00060 S. Maria di Galeria (Roma), Italy; e-mail: daniela.meloni@casaccia.enea.it

(*) Now also at: Dipartimento di Fisica, Università «La Sapienza», Roma.
(Tevini, 1993). While the relationship between total ozone and UV irradiance is well established (e.g., McKenzie et al., 1995; Zerefos et al., 1995, and others), the trend due to atmospheric parameters like tropospheric ozone, aerosols and clouds still has to be quantified. The increase in tropospheric ozone following photochemical production due to growing emissions of $\mathrm{NO}_{x}$ in the industrialized regions of the Northern Hemisphere could mask the effect of the decrease in stratospheric ozone, especially in summer (Brühl and Crutzen, 1989). Besides tropospheric ozone, aerosols should be considered as well. Aerosols are a major component of the climate system, though mostly still unknown. They can affect the radiative field both with direct and indirect effects, by absorbing and scattering the incoming solar radiation and by modifying cloud properties and the hydrological cycle acting as cloud condensation nuclei (Twomey, 1977; Charlson et al., 1992; Schwartz and Andreae, 1996).

Aerosol effects on the UV irradiance have been studied by several authors, through both field observations and radiative transfer model 
calculations. Liu et al. (1991) showed that the observed reduction in ground level visibility since the industrial revolution over non urban areas in the Eastern United States and Europe may have balanced most of the increase in UVB due to stratospheric ozone depletion. Studies have been conducted at continental sites in North America (DeLuisi, 1997; Kerr, 1997) and in Europe (Krzyścin and Puchalski, 1998; Cañada et al., 2000) which show how aerosol optical depth and aerosol characteristics can affect UV irradiance.

In the Mediterranean basin, investigations have been carried out at coastal (Kylling et al., 1998; Cañada et al., 2000), rural (Meleti and Cappellani, 2000) and urban sites (Lorente et al., 1994; Repapis et al., 1998). In particular, the Mediterranean experiences high mineral aerosol loads due to the transport of dust particles from the Sahara, mainly in spring and summer (di Sarra et al., 2001a). The Sahara is one of the major sources of mineral aerosols worldwide (Morales, 1986). Mineral aerosols are a major class of tropospheric aerosols and are expected to have a considerable influence on the Earth radiative budget (Schwartz and Andreae, 1996). Dust is a mixture of various minerals, and its optical constants depend on origin, mobilization properties, physical and chemical transformation during transport in the atmosphere, as well as how minerals are aggregated. Sokolik and Toon (1996) estimated that, although the key quantities which influence the direct radiative forcing are affected by a wide range of uncertainties, the regional forcing due to mineral aerosols can be of the order of $20 \mathrm{~W} / \mathrm{m}^{2}$ locally, comparable to the forcings observed for clouds. Although desert dust has a big impact on UV radiation through scattering and absorption, only a few studies on this topic have been carried out.

Since 1997, the Italian National Agency for New Technology, Energy, and Environment (ENEA) has maintained a Station for Climate Observations at the island of Lampedusa $\left(35.5^{\circ} \mathrm{N}, 12.6^{\circ} \mathrm{E}\right)$, in the Southern Mediterranean, approximately $100 \mathrm{~km}$ off the west coast of Tunisia. Several atmospheric parameters (greenhouse gas concentrations, measured at Lampedusa since 1992, meteorological parameters, total ozone, aerosol optical depth and solar ra- diation) are monitored continuously. A doublemonochromator Brewer MKIII performs measurements of total ozone, UV irradiance and aerosols.

In May and June 1999, the PAUR II campaign (Photochemical Activity and Ultraviolet Radiation modulation factors) took place at Lampedusa, with the aim of studying the role of ozone and aerosols on the transfer of ultraviolet and visible radiation through the atmosphere (di Sarra et al., 2001b). The island, isolated from continental and polluted sites, is particularly suitable for studies of desert aerosols, which often reach the measuring site, especially in summer, as well as for the observation of the effects produced by aerosols of different origin on the radiative budget. In previous papers the evident effect of the Saharan dust aerosols on the UV, erythemal, and visible irradiance has been shown (di Sarra et al., 2001b, 2002).

In this paper, the measured Brewer spectra are simulated by means of a radiative transfer model for cloud free conditions in order to study the dependence of UV radiation on aerosol load and on particle optical properties. The model is initialized with a large set of observations, allowing a detailed characterization of the atmospheric properties.

\section{Radiative transfer model}

In this study the UVSPEC model by Mayer et al. (1997) is used. The model is based on the discrete ordinate method (Stamnes et al., 1988) for the solution of the radiative transfer equation, and irradiances are computed with the pseudospherical approximation (Dahlback and Stamnes, 1991) which accounts for the sphericity of the atmosphere.

The model can simulate radiance, direct and diffuse irradiance and actinic fluxes between 200 and $800 \mathrm{~nm}$ assuming an extraterrestrial solar spectrum and taking into account the atmospheric structure and composition.

The high resolution extraterrestrial spectrum is from Atlas 3 shifted to air wavelength between 280 and $407.8 \mathrm{~nm}$, from Atlas 2 from 407.8 and $419.9 \mathrm{~nm}$, and from the Modtran 3.5 model above $419.9 \mathrm{~nm}$ (Kylling et al., 1998). 
Temperature dependent ozone cross-sections used for model simulations are from Burrows et al. (1999) for the 280-794 $\mathrm{nm}$ range.

To accurately account for the variation of the optical properties with altitude, the atmosphere was divided in 64 layers from 0 to $120 \mathrm{~km}$ with a vertical resolution of $150 \mathrm{~m}$ in the lowest 2.1 $\mathrm{km}, 300 \mathrm{~m}$ between 2.1 and $8.1 \mathrm{~km}, 1 \mathrm{~km}$ until $25 \mathrm{~km}$ and progressively increasing thickness up to $120 \mathrm{~km}$.

The model inputs are: solar zenith angle; total ozone; surface albedo; vertical profiles of pressure, temperature, air and ozone density. Aerosols are also characterised through singlescattering albedo $\omega_{0}$, asymmetry factor $g$ and optical depth profile.

Some of the model input parameters had to be assumed due to lack of measurements. The albedo was estimated as an average of the wavelength dependent vegetation and water albedoes weighted for the respective areas within a region of $20 \mathrm{~km}$ radius around the site (Ruggaber, 1998). Since Lampedusa is relatively small (surface area of about $20 \mathrm{~km}^{2}$ ), the albedo we used is very close to that of sea water (see Doda and Green, 1980). The surface is assumed to be Lambertian in the model.

Vertical profiles of pressure and temperature at 12:00 UT were obtained from the National Centers for Environmental Prediction (NCEP) analyses, and the molecular density profile is calculated in the hypothesis of perfect gas behaviour.

The total columnar ozone and its vertical distribution as well as the Aerosol Optical Depth (AOD), vertical extinction profile and size distribution have been directly measured or derived from measured data, as described in the following paragraph.

The original model has been modified to take into account the vertical distribution of the aerosol single scattering albedo and asymmetry factor and to include various tropospheric aerosol types, whose spectral optical properties have been calculated applying the Mie theory.

The calculated spectral irradiances are convoluted with the Brewer slit function, assumed to be wavelength-independent and approximated by a triangle with $0.55 \mathrm{~nm} \mathrm{FWHM}$ bandwidth.

\section{Measurements}

Measurements of total columnar ozone and UV irradiance have been continuously made by means of the Brewer spectrophotometer \#123 since January 1998. A description of the instrument and of its operational mode is given in Kerr et al. (1985). The Brewer was originally designed for total ozone measurements and is able to perform reliable UV measurements. The double monochromator MK III measures spectral global irradiance between 286.5 and 363 $\mathrm{nm}$ at steps of $0.5 \mathrm{~nm}$ with a resolution of 0.55 $\mathrm{nm}$ through a teflon diffuser: the suppression of stray light results in an improvement in the UV measurements below $305 \mathrm{~nm}$ with respect to the single monochromator Brewer MK II (Bais et al., 1996). The Brewer \#123 was calibrated for ozone measurements in July 1998 by comparison with the travelling Brewer \#17. Global UV irradiance has been absolutely calibrated with a $1000 \mathrm{~W}$ lamp traceable to the National Institute of Standards and Technology (NIST) and its stability is regularly checked by using $50 \mathrm{~W}$ external lamps.

Aerosol optical depth measurements were made by sun photometric methodology, using the Brewer MK III spectrophotometer \#123 and a Multi-Filter Rotating Shadowband Radiometer (MFRSR). The methodology to derive the AOD from the Brewer is based on the data of the total ozone measurements and is fully described in Marenco et al. (2002). Calibration was obtained at sea level with Langley plots for a large number of clear days, and averaged to remove residual atmospheric disturbances. This methodology provided an uncertainty of less than $2 \%$ on the instrument calibration constant. Since during normal operation the instrument takes measurements using different neutral density filters, their transmissivity also had to be determined.

A description of the MFRSR can be found in Harrison et al. (1994).

The methodology used to derive aerosol optical depth from MFRSR data has been described in di Sarra et al. (2002). This instrument has six channels centered at 415, 500, $615,671,868$, and $937 \mathrm{~nm}$ (10 nm bandwidth). The data used in this work refer to the $415 \mathrm{~nm}$ and 
$868 \mathrm{~nm}$ bands. The calibration of the MFRSR is also based on Langley plots, performed for five selected cloud-free and low aerosol mornings, with an uncertainty on the instrument calibration constant of $2 \%$ at $868 \mathrm{~nm}$ and $5 \%$ at $415 \mathrm{~nm}$.

The derived aerosol optical depths measured with the two instruments during PAUR II appear consistent (see for instance fig. 2a,b).

During the PAUR II campaign, besides the Brewer and the MFRSR, other instruments were deployed at the ENEA station, and were operated during daytime: UV-A and UV-B radiometers, solar pyranometers, a GUV-511 band radiometer, a POM-01L aureole sensor, a LI-1800 visible spectrometer, an aerosol lidar, and meteorological sensors.

Additional instruments were installed aboard the ultralight aircraft of the Fraunhofer Institut für Atmosphärische Umweltforschung (IFU, Germany): a UV photometer for determination of ozone concentration, a FSSP-100 optical particle counter, a TSI-3010 condensation nuclei counter, a laser particle counter, an AVM III aerosol scatterometer, two solar pyranometers (upward and downward looking), an UV-B radiometer, two $\mathrm{JO}\left({ }^{1} \mathrm{D}\right)$ and two $\mathrm{JNO}_{2}$ filter radiometers (upward and downward looking), digital cameras, pressure, temperature, humidity and position sensors. Profiles of ozone, radiation, and aerosol properties were determined during 16 flights carried out from the Lampedusa airport in May, reaching a maximum altitude of $4.5 \mathrm{~km}$. A description of the instrumented aircraft together with some results of the measurements at Lampedusa are reported by Junkermann (2001).

The ozone profiles needed by the model are taken from Bhartia et al. (1985) who computed standard middle latitude profiles derived from Solar Backscatter Ultraviolet (SBUV) and balloon observations. In the lower atmospheric layers the standard profile has been replaced with the profile measured by the ozone UVphotometer installed aboard the aircraft and the whole profile is scaled to match the columnar ozone measured by the Brewer.

The aerosol vertical profile was observed by lidar (di Sarra et al., 2001a). The aerosol optical depth at $532 \mathrm{~nm}$ was obtained by interpolation with a power law from the measurements per- formed by the MFRSR at $415 \mathrm{~nm}$ and $868 \mathrm{~nm}$. The vertical extinction profiles at $532 \mathrm{~nm}$ were derived from the analysis of the lidar and the particle counters profiles as described in Di Iorio et al. (2003). From the top of the aerosol layer to $10 \mathrm{~km}$ altitude the tropospheric aerosol type was assumed, and background stratospheric aerosol from 10 to $30 \mathrm{~km}$ (Shettle,1989).

The aerosol size distribution was retrieved from the data collected during the aircraft flights by FSSP and condensation nuclei counter (Di Iorio et al., 2003), whereas the dry mass refractive indices are the only unknown parameters. The aerosol refractive index for each examined day was determined: this was done by calculating the aerosol single scattering albedo and asymmetry factor using the retrieved size distributions for different values of the real and imaginary parts of the refractive index; then the aerosol refractive index which minimizes the differences between measured and modelled spectral irradiances was chosen.

\section{Results and discussion}

Spectral UV irradiances obtained on two clear-sky days, May 14 and 28, characterized by different aerosol loadings were selected. Table I summarizes some relevant information for the two cases.

Measured UV spectra were corrected for the Sun-Earth distance and, together with $\mathrm{O}_{3}$ total columns, interpolated at the $20^{\circ}$ solar zenith angle. The interpolation of the spectra was made with a second order polynomial, using the three acquired spectra which are closest to the time corresponding to the given solar zenith angle. Linear interpolation is used to derive the total ozone amounts at the given solar zenith angle.

Figure 1a,b depicts the ultraviolet spectra measured at $20^{\circ}$ solar zenith angle on May 14 and 28 and their ratio. It should be noted that at $20^{\circ}$ solar zenith angle (around 10:20 UT for May 14 and 10:10 UT for May 28) the aerosol optical depths at $320.1 \mathrm{~nm}$ are equivalent within the standard deviations, while they differ at $532 \mathrm{~nm}$, with the AOD of May 14 being greater than that of May 28 (see table I). 

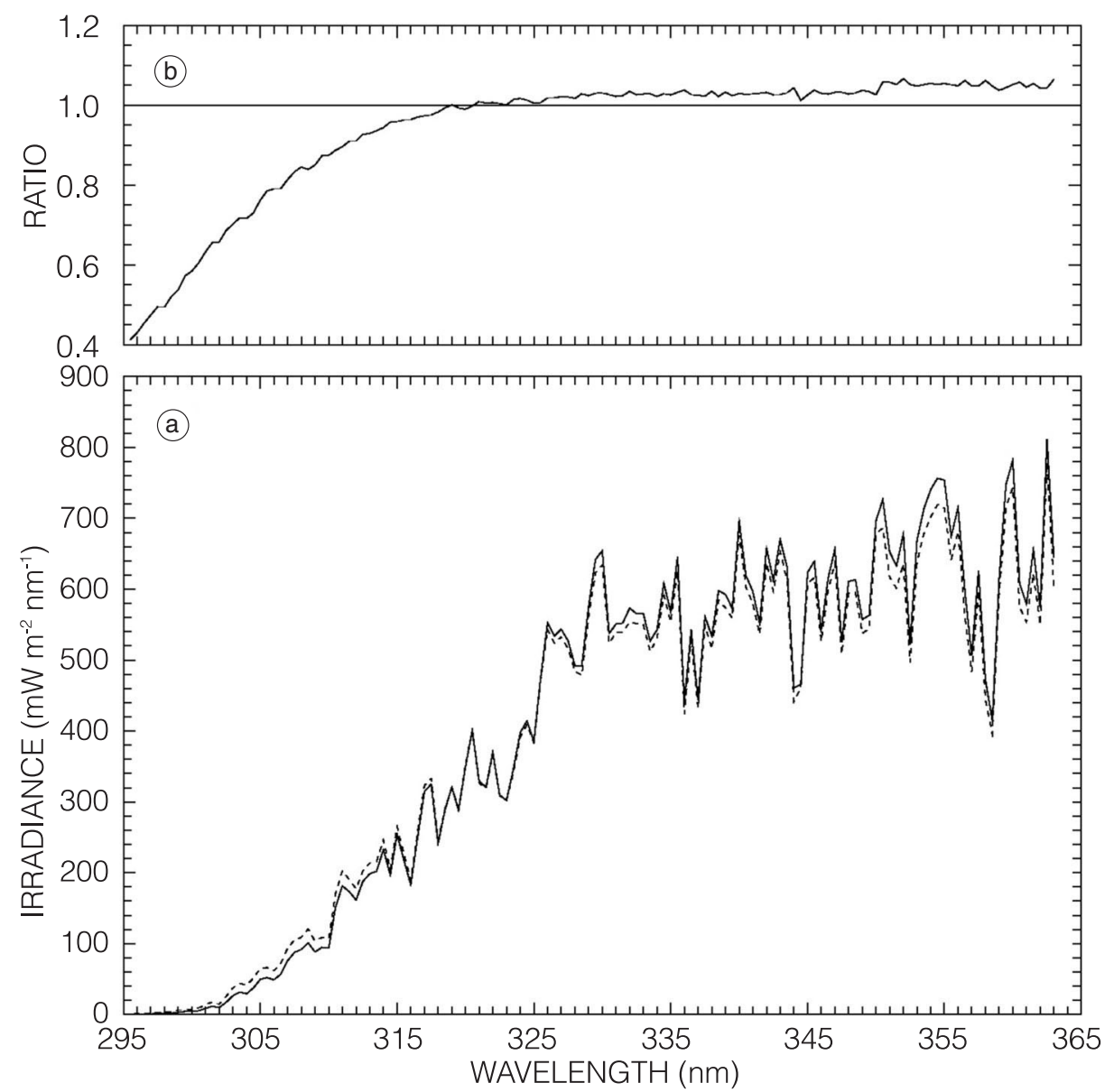

Fig. 1a,b. a) Measured spectral global irradiance on May 28 (solid line) and on May 14 (dashed line); b) their ratio.

Table I. Model input parameters.

\begin{tabular}{ccccc}
\hline \hline Day & Solar zenith angle & AOD $(320 \mathrm{~nm})$ & AOD $(532 \mathrm{~nm})$ & Ozone (DU) \\
\hline $14 / 05 / 1999$ & $20^{\circ}$ & $0.384 \pm 0.018$ & $0.392 \pm 0.007$ & 295.1 \\
$28 / 05 / 1999$ & $20^{\circ}$ & $0.375 \pm 0.019$ & $0.276 \pm 0.007$ & 343.7 \\
\hline
\end{tabular}

On May 14, the aerosol optical depth at $532 \mathrm{~nm}$ is relatively high and the columnar ozone is low, while the opposite occurs on May 28. The negative correlation between aerosol optical depth and total ozone can be explained in terms of transport patterns (di Sarra et al., 2002). Significant differences in the measured irradiances appear. At short wavelengths, the effect of ozone absorption is dominating, and higher irradiances are observed on May 14 when 
the total ozone is low. At longer wavelengths the effect of the aerosol overcomes the effect of the ozone, and higher irradiances are found on May 28 , a day characterized by low aerosol optical depth. The ratio is 1 around $320 \mathrm{~nm}$, a wavelength which is only weakly absorbed by ozone, and where the two AODs coincide. According to the 10-day isentropic trajectories ending at Lampedusa at approximately $2.5 \mathrm{~km}$ height, in May 14 the air masses arrived at Lampedusa after spending several days over the Sahara desert, and the aerosol composition is expected to be mainly of mineral dust. The air mass reaching the island on May 28 had passed over Europe, thus suggesting that the aerosol may contain particles of anthropic origin as well as marine. The trajectories were derived with the National Aeronautics and Space Administration Trajectory Model (Schoeberl et al., 1992), which uses the National Centers for Environmental Prediction (NCEP) analyses.

Figure 2a,b shows the daily evolution of the AOD at $320.1 \mathrm{~nm}$ as derived from Brewer direct sun measurements in May 14 and 28. Also depicted are the AODs at $415 \mathrm{~nm}$ and $868 \mathrm{~nm}$ from MFRSR measurements. It can be seen that on both days the AODs at the three wavelengths show the same behaviour. The aerosol optical depths at 320.1 and $415 \mathrm{~nm}$ are always very close; an exception is represented by the time interval between approximately 10:30 and 15 on May 14, when the curve corresponding to $320.1 \mathrm{~nm}$ is below the other two. This may be due to the presence of clouds or may reflect a misalignment of the MFRSR leading to an underestimation of the direct irradiance and thus to an overestimation of aerosol optical depth. The wavelength dependence of the AOD can be expressed through the Ångström exponent $\alpha$

$$
\alpha=\left(\ln \frac{\operatorname{AOD}\left(\lambda_{1}\right)}{\operatorname{AOD}\left(\lambda_{2}\right)}\right) \cdot\left(\ln \frac{\lambda_{2}}{\lambda_{1}}\right)^{-1}
$$

According to di Sarra et al. (2001a, 2002), low and high $\alpha$ values characterize days with Saharan and continental-maritime aerosol during PAUR II, respectively. The Ångström exponent calculated using the AODs at $415 \mathrm{~nm}$ and 868 $\mathrm{nm}$ is 0.11 for May 14 and 1.21 for May $28\left(20^{\circ}\right.$ solar zenith angle).
To evaluate the impact of aerosols on radiative budget, it is necessary to have the best knowledge of the aerosol optical properties that can be obtained from the available information. A retrieval of the aerosol size distribution for May 14 was not possible due to the presence of clouds during the aircraft flight, therefore the model simulation is performed using the aerosol size distributions of a day with similar atmospheric conditions, May 18. For the calculation of May 28 the aerosol size distribution of May 27 was available.

The complex refractive indices for the aerosols were chosen as the values which give $\omega_{0}$ and $g$ in best agreement with global UV irradiance measurements (assuming to have no wavelength dependence): 1.5-0.0042 $i$ for May 14 and 1.5-0.026 $i$ for May 28. The imaginary part of the refractive index for May 14 is compatible with the values reported by Patterson et al. (1977) and Sokolik et al. (1993) for mineral dust.

The airmass that reaches Lampedusa on May 28 was over Europe the previous days, and the aerosols may reasonably contain anthropogenic absorbing particles including black carbon. d'Almeida et al. (1991) disclosed that the refractive index values for black carbon show differences up to a factor of 3 in the imaginary part, and by more than $50 \%$ in the real part. This may lead to very different effects on atmospheric radiative budget. Aerosols with a high imaginary part have strong absorption properties, thus determining a net warming effect, while aerosols with a low imaginary part have a cooling effect, mainly producing an increase of the scattering of the incoming radiation back to space.

Table II displays the single scattering albedoes and the asymmetry factors calculated at $500 \mathrm{~nm}$ with the Mie code using the above mentioned size distributions and refractive indices; for comparison, $\omega_{0}$ and $g$ from d'Almeida et al. (1991) for the desert (May14) and the maritime polluted (May 28) aerosol types are reported: the latter values refer to July and for a relative humidity of $0 \%$. The range of variability for the calculated $\omega_{0}$ and $g$ are due to the changes of the measured size distribution with altitude.

The results of the radiative transfer calculations are shown in fig. $3 a, b$ as the ratio of the model result and the measured spectrum. The comparisons show an agreement within $8 \%$ 

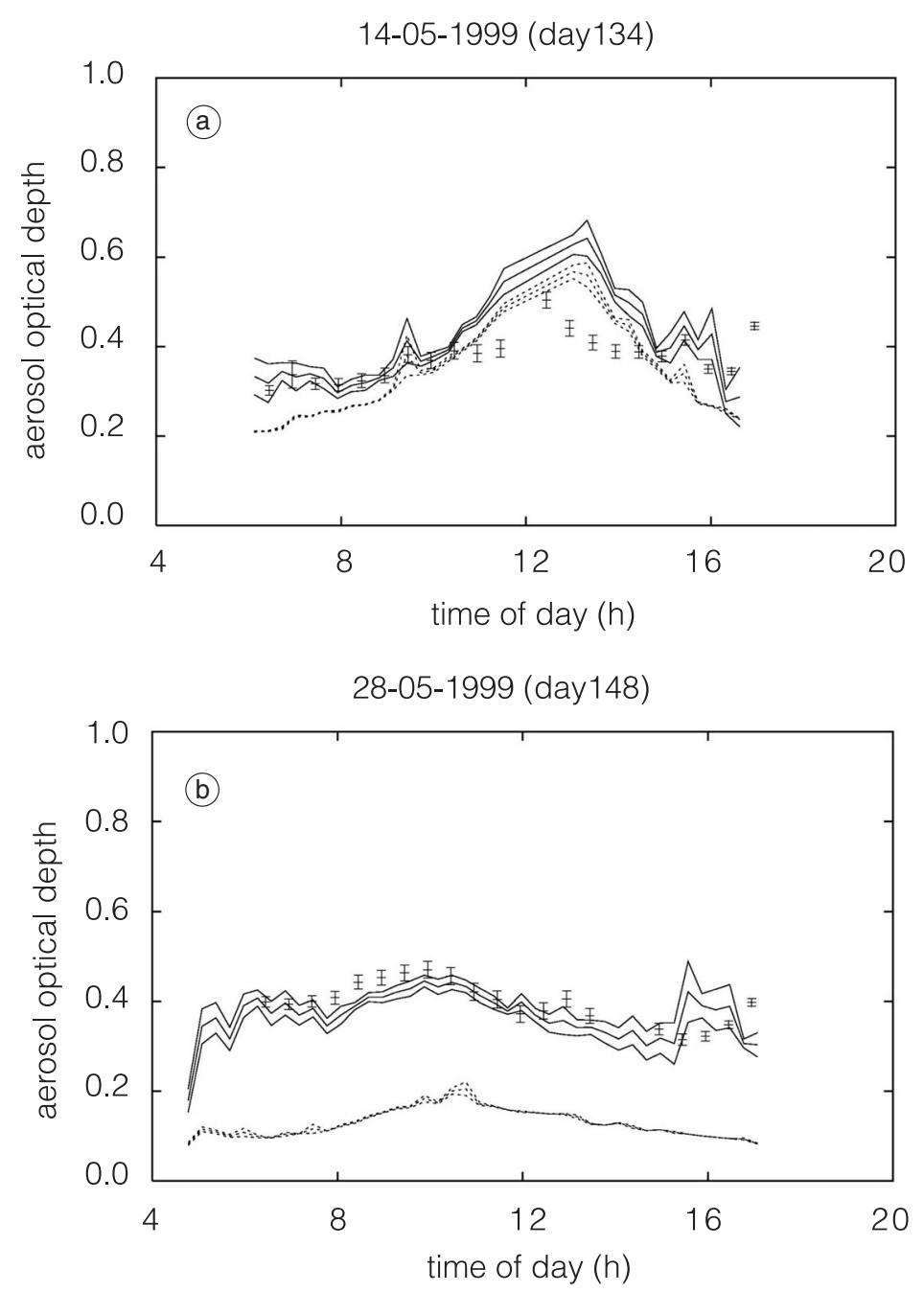

Fig. 2a,b. Daily evolution of the aerosol optical depth for May 14 (a) and May 28 (b) at three wavelengths: $320.1 \mathrm{~nm}$ (single points with error bars) from Brewer measurements, $415 \mathrm{~nm}$ (solid line) and $868 \mathrm{~nm}$ (dashed line) from MFRSR measurements. Also shown is the uncertainty range in the MFRSR aerosol optical depth at 415 and $868 \mathrm{~nm}$.

Table II. Refractive index and single scattering albedo $\omega_{0}$ and asymmetry factor $g$ at $500 \mathrm{~nm}$ derived for May 14 and May 28 by Mie calculation and comparison with the values reported in d'Almeida et al. (1991) for the desert (May 14) and the maritime polluted (May 28) aerosol types on July and for a relative humidity of $0 \%$.

\begin{tabular}{|c|c|c|c|c|c|}
\hline \multirow[b]{2}{*}{ Day } & \multirow[b]{2}{*}{$\begin{array}{l}\text { Refractive } \\
\text { index }\end{array}$} & \multicolumn{2}{|c|}{$\omega_{0}$} & \multicolumn{2}{|c|}{$g$} \\
\hline & & Calculation & d'Almeida & Calculation & d'Almeida \\
\hline 14/05/1999 & $1.5-0.0042 i$ & $0.75-0.76$ & $0.725-0.777$ & $0.81-0.82$ & $0.778-0.822$ \\
\hline 28/05/1999 & $1.5-0.026 i$ & $0.69-0.75$ & 0.960 & $0.58-0.67$ & 0.692 \\
\hline
\end{tabular}



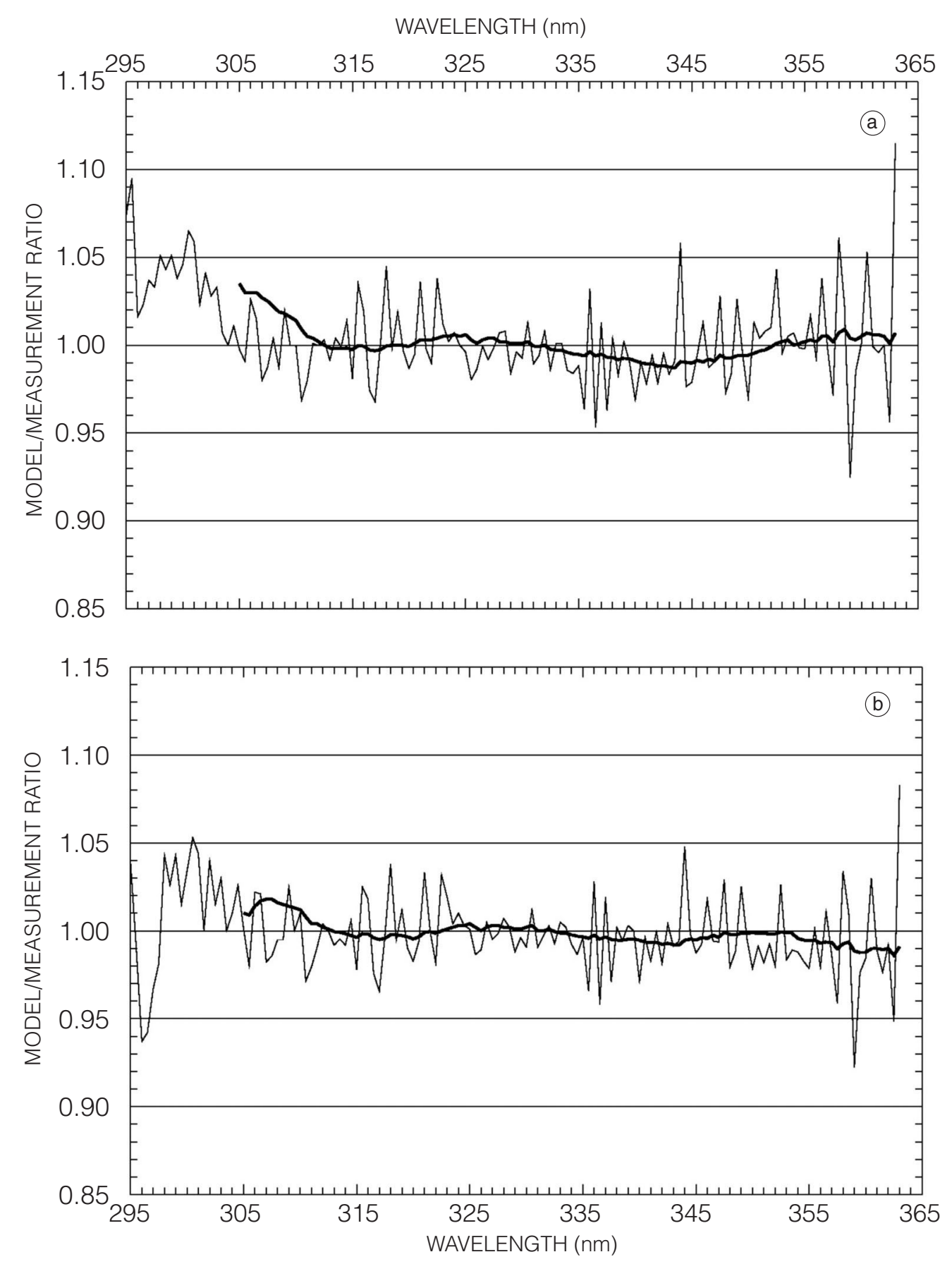

Fig. 3a,b. Ratio of modelled to measured spectral irradiance for May 14 (a) and May 28 (b). The thick solid curve represents a $10 \mathrm{~nm}$-running mean. 
Table III. Aerosol radiative forcing (units of $\mathrm{W} / \mathrm{m}^{2}$ ) at the ground and at the top of the atmosphere (assumed here at $120 \mathrm{~km}$ ) calculated for May 14 and 28 for the Brewer operational range $(286.5-363.0 \mathrm{~nm})$ and in the UV-B spectral range (280-320 nm). This is different from the usual SW radiative forcing (see text).

\begin{tabular}{cccccc}
\hline \hline & \multicolumn{2}{c}{ May 14 } & & \multicolumn{2}{c}{ May 28 } \\
\cline { 2 - 3 } \cline { 5 - 6 } Altitude $(\mathrm{km})$ & Brewer & UV-B & & Brewer & UV-B \\
\hline 0 & -4.63 & -0.57 & & -3.55 & -0.40 \\
$120($ TOA $)$ & -0.72 & -0.06 & & +0.27 & +0.01 \\
\hline
\end{tabular}

(single wavelength peaks) in the 296-362 nm region for both days; below $296 \mathrm{~nm}$, the differences become slightly larger due to the higher uncertainties in the irradiance measurements (attributed to the decrease of the signal and to the effects of stray light). The peak in the model/ measurement ratio is attributed to the differences between the true slit function of the Brewer and the one modelled to reproduce the spectra and to the adopted extraterrestrial spectrum.

To remove this effect, a 10 nm-running mean was calculated. If this curve is considered the agreement between model and measurements is within $3 \%$.

The model also evaluates the attenuation of irradiance due to aerosols. At $350 \mathrm{~nm}$ it is $12.5 \%$ for May 28 and $16.7 \%$ for May 14 with respect to the aerosol-free case.

The model allows the calculation of the aerosol radiative forcing at different altitudes: at the ground it is defined as the difference between the downward global irradiance with and without aerosols respectively, while at the Top Of the Atmosphere (TOA) it is the difference between upward diffuse irradiance with and without aerosols, so that negative values indicate a greater upward irradiance for the aerosol free case. The values in the Brewer $(286.5-363.0 \mathrm{~nm})$ and in the UV-B (280-320 nm) spectral ranges are shown in table III.

The negative forcing at the surface for both days is due to the loss of radiation by absorption and backscattering. The aerosol on May 14 attenuates the incoming radiation more than on May 28, due to larger absorption by desert aerosols: the coalbedo $\left(1-\omega_{0}\right)$, which represents the fraction of radiation that has been absorbed, is 0.24-0.26 for May 14 and 0.16-0.21 for May 28 at $320 \mathrm{~nm}$. At the TOA we can observe opposite effects for the two cases. In other words, the aerosol layer reduces the atmospheric albedo: although the imaginary part of the aerosol refractive index is not high, the overall effect is a subtraction of upward irradiance with respect to the aerosol-free case. On May 28 backscattering prevails, thereby causing a major fraction of incoming radiation to be reflected.

It must be remarked that calculations of the local radiative forcing are made in the UV portion of the solar spectrum where the Brewer operates (286.5-363.0 nm). This is different from the usual shortwave (SW) radiative forcing which is conventionally related to the $(0.28-4.3 \mu \mathrm{m})$. Several studies have been performed to estimate the aerosol radiative forcing due to airborne Saharan dust. For example, Ackerman and Chung (1992) found from the NOAA-9 ERBE observations that the presence of dust increased the shortwave (SW) exitance at the TOA over ocean by $40-90 \mathrm{~W} / \mathrm{m}^{2}$. Hsu et al. (2000) derived the TOA direct forcing of Saharan dust using satellite data from TOMS and ERBE; they found values of $20-100 \mathrm{~W} / \mathrm{m}^{2}$ in the SW over the ocean. A comparison of our results with previous works is not possible since the radiative model we used performs calculations for a maximum wavelength of $800 \mathrm{~nm}$.

The island of Lampedusa is small (area of approximately $20 \mathrm{~km}^{2}$ ) and produces a limited perturbation to the radiative field over the sea: this explains why we simulate the radiative field using an albedo very close to that of water. A change in surface albedo passing from sea to ground can cause important differences in the aerosol radiative forcing (Ackerman and Chung, 1992; Sokolik and Toon, 1996; Hsu et al., 2000). 


\section{Acknowledgements}

Measurements at Lampedusa were partly supported by the European Union, Agenzia Spaziale Italiana, and Ministero per l'Ambiente of Italy. We would like to thank M. Cacciani, T. Di Iorio, G. Fiocco, and D. Fuà for providing the lidar data, T. Di Iorio for the aerosol size distributions, J.J. DeLuisi for the MFRSR data. Contributions at Lampedusa by P. Chamard, L. De Silvestri, P. Grigioni, and F. Monteleone are gratefully acknowledged. We also thank B. Mayer and A. Kylling for their helpful suggestions on the radiative transfer model.

\section{REFERENCES}

ACKerman, S.A. and H. CHUnG (1992): Radiative effects of airborne on regional energy budgets at the top of the atmosphere, J. Appl. Meteor., 31, 223-241.

Bais, A.F., C.S. Zerefos and C.T. MCElroy (1996): Solar UVB measurements with the double-and singlemonochromator Brewer ozone spectrophotometers, Geophys. Res. Lett., 23, 833-836.

Bhartia, P.K., D. Silberstein, B. Monosmith and A.J. FLEIG (1985): Standard profiles of ozone from ground to $60 \mathrm{~km}$ obtained by combining satellite and ground based measurements, in Atmospheric Ozone, edited by C.S. ZEREFOS and A. GHAZI (Reidel Publishing Company, Dordrecht, The Nederlands), 243-247.

BRÜHL, C. and P.J. CRUTZEN (1989): On the disproportionate role of tropospheric ozone as a filter against solar UV-B radiation, Geophys. Res. Lett., 16, 703-706.

Burrows, J.P., A. DEHn, B. Deters, S. Himmelmann, A. RiCHTER, S. VOIGT and J. ORPHAL (1999): Atmospheric remote-sensing reference data from GOME: 2. temperature-dependent absorption cross sections of $\mathrm{O}_{3}$ in the 231-794 nm range, J. Quant. Spectrosc. Radiat. Transfer, 61, 509-517.

CAÑAdA, J., G. PEdRós, A. LóPEZ and J.V. Boscá (2000): Influences of the clearness index for the whole spectrum and of the relative optical air mass on UV solar irradiance for two locations in the Mediterranean area, Valencia and Cordoba, J. Geophys. Res., 105, 4759-4766.

Charlson, R.J., S.E. SchwartZ, J.M. Hales, R.D. Cess, J.A. COAKLEY Jr., J.E. HANSEN and D.J. HOFMANN (1992): Climate forcing by anthropogenic aerosols, Science, 255, 423-430.

D'AlmeidA, G.A., P. KoepKe and E.P. Shettle (1991): Atmospheric Aerosols Global Climatology and Radiative Characteristics (A. Deepak Publication, Hampton, Va), pp. 561 .

Dahlback, A. and K. Stamnes (1991): A new spherical model for computing the radiation field available for photolysis and heating at twilight, Planet. Space Sci., 39, 671-683.

DeLuisi, J. (1997): Atmospheric ultraviolet radiation scattering and absorption, in Solar Ultraviolet Radiation, Modelling, Measurements, and Effects, NATO ASI Series, vol. I 52, edited by C.S. ZEREFOS and A.F. BAIS (Springer-Verlag, Berlin, Germany), 65-84.

Di IORIO, T., A. DI SARRA, W. JUNKERMANN, M. CACCIANI, G. FIOCCO and D. FUÀ (2003): Tropospheric aerosols in the Mediterranean: 1. Microphysical and optical properties, J. Geophys. Res., 108, doi: 10.1029/2002JD002815 (in press).

Di SARRA, A., T. Di IORIO, M. CACCIANI, G. FIOCCO and D. FUÀ (2001a): Saharan dust profiles measured by lidar at Lampedusa, J. Geophys. Res., 106, 10,335-10,348.

Di SARRA, A., M. CACCIANI, M. CAMPANELli, P. Chamard, C. Cornwall, J. Deluisi, L. De Silvestri, T. Di Iorio, P. Disterhoft, G. FiocCo, D. FuÀ, P. Grigioni, W. JunkeRmann, F. MARENCO, D. MELONI, F. MONTELEONE and B. OliVIERI (2001b): Radiation, ozone, and aerosol measurements at Lampedusa during the PAUR II Campaign, in IRS 2000: Current Problems in Atmospheric Radiation, edited by W.L. SMITH and YU. M. TIMOFEYEV (A. Deepak Publishing, Hampton, Virginia), 1193-1196.

Di SARRA, A., M. CACCIANI, P. Chamard, C. CoRnWAll, J.J. Deluisi, P. Disterhoft, T. Di IORIO, G. FiocCo, D. FUÀ and F. MONTELEONE (2002): Effects of desert dust and ozone on the ultraviolet irradiance: observations at Lampedusa during PAUR II, J. Geophys. Res., 107 (D18), 8135, doi:10.1029/2000JD000139.

DODA, D.D. and A.E.S. GREEN (1980): Surface reflectance measurements in the UV from an airborne platform. Part I, Appl. Opt., 19, 2140-2145.

HARRIS, N.R.P., G. ANCELlET, L. Bishop, D.J. HOFMANN, J.B. KERR, R.D. MCPETERS, M. PRENDEZ, W.J. RANDEL, J. Staehelin, B.H. Subbaraya, A. Volz-Thomas, J. ZAWODNY and C.S. ZEREFOS (1997): Trends in stratospheric and tropospheric ozone, J. Geophys. Res., 102, 1571-1588.

HARRison, L., J. Michalsky and J. BERndT (1994). Automated multifilter rotating shadow-band radiometer: an instrument for optical depth and radiation measurements, Appl. Opt., 33, 5118-5125.

Hsu, N.C., J.R. HeRman and C. WeAver (2000). Determination of radiative forcing of Saharan dust using combined TOMS and ERBE data, J. Geophys. Res., 105, 20,649-20,661.

JUNKERMANN, W. (2001): An ultralight aircraft as platform for research in the lower troposphere: system performance and first results from radiation transfer studies in stratiform aerosol layers and broken cloud conditions, J. Atmos. Ocean. Tech., 18, 934-946.

KERR, J.B. (1997): Observed dependencies of atmospheric UV radiation and trends, in Solar Ultraviolet Radiation, Modelling, Measurements, and Effects, NATO ASI Series, vol. I 52, edited by C.S. ZEREFOS and A.F. BAIS (Springer-Verlag, Berlin, Germany), 65-84.

KerR, J.B., C.T. MCELROY, D.I. WARDLE, R.A. OlaFson and W.F.J. Evans (1985): The authomated Brewer spectrophotometer, in Atmospheric Ozone, edited by C.S. Zerefos and A. GHAZI (D. Reidel Publishing, Dordrecht, Holland), 396-401.

KRZYŚCIN, J.W. and S. PUCHALSKI (1998): Aerosol impact 
on the surface UV radiation from the ground-based measurements taken at Belk, Poland, 1980-1996, J. Geophys. Res., 103, 16,175-16,181.

KYlling, A., A.F. BAIS, M. BlumthaleR, J. SCHREDER, C.S ZEREFOS and E. KOSMIDIS (1998): Effect of aerosols on solar UV irradiances during the photochemical activity and solar ultraviolet radiation campaign, J. Geophys. Res., 103, 26,051-26,060.

LIU, S.C., S.A. MCKEEN and S. MADRONICH (1991): Effect of anthropogenic aerosols on biologically active ultraviolet radiation, Geophys. Res. Lett., 18, 2265-2268.

Lorente, J., A. REDAÑ and X. DE CABo (1994): Influence of urban aerosol on spectral solar irradiance, J. Appl. Meteorol., 33, 406-415.

MADRONICH, S. (1992): Implications of recent total atmospheric ozone measurements for biologically active ultraviolet radiation reaching the Earth's surface, Geophys. Res. Lett., 19, 37-40.

Marenco, F., A. Di SARRA and J. Deluisi (2002): A methodology for determination of aerosol optical depth from the Brewer 300-320 nm ozone measurements, Appl. Opt., LP, 41, 1805-1814.

MAYER, B., G. SECKMAYER and A. KYlling (1997): Systematic long-term comparison of spectral UV measurements and UVSPEC modeling results, $J$. Geophys. Res., 102, 8755-8767.

McKenzie, R.L., M. Blumthaler, C.R. Booth, S.B. DiAZ, J.E. FreDERCK, T. ITO, S. MADRONICH and G SECKMEYER (1995): UNEP/WMO Scientific Assessment of Ozone Depletion, chapter 9, Surface Ultraviolet Radiation, United Nations Econ. Programme, Nairobi, Kenya.

MelETI, C. and F. CAPPELlANi (2000): Measurements of aerosol optical depth at Ispra: analysis of the correlation with UV-B, UV-A, and total solar irradiance, J. Geophys. Res., 105, 4971-4978.

MORALES, C. (1986): The airborne transport of Saharan dust: a review, Climatic Change, 9, 219-241.

PATTERSON, E.M., D.A. GILLETTE and B.H. STOCKTON (1977): Complex index of refraction between 300 and $700 \mathrm{~nm}$ for Saharan aerosols, J. Geophys. Res., 82, 3153-3161.

Repapis, C.C., H.T. Mantis, A.G. Paliatsos, C.M.
Philandras, A.F. Bais and C. Meleti (1998): Case study of UV-B modification during episodes of urban air pollution, Atmos. Environ., 32, 2203-2208.

RUGGABER, A. (1998): Spectral ground albedo in the UVrange, paper presented at the European Conference on Atmospheric UV Radiation (ECUV), Helsinki, 29 June2 July 1998, Finn. Meteorol. Inst.

SChOEBERL, M.R., L.R. LAIT, P.A. NEWMAN and J.S. ROSENFIELD (1992): The structure of the polar vortex, J. Geophys. Res., 97, 7859-7882.

SCHWARTZ, S.E. and M.O. ANDREAE (1996): Uncertainty in climate change caused by aerosols, Science, 272, 1121-1122.

SHETTLE, E.P. (1989): Models of aerosol, clouds and precipitation for atmospheric propagation studies, paper presented at Conference on Atmospheric Propagation in the UV, Visible, IR and MM-Region and Related System Aspects, NATO Adv. Group for Aerosp. Res. and Dev., Copenhagen.

SoKOLIK, I.N. and O.B. ToON (1996): Direct radiative forcing by anthropogenic airborne mineral aerosols, Nature, 381, 681-683.

SOKOLIK, I., A. ANDRONOVA and T.C. JOHNSON (1993): Complex refractive index of atmospheric dust aerosols, Atmos. Environ., 27A, 2495-2502.

Stamnes, K., S.-C. TSAY, W. Wiscombe and K. JAYAWEERA (1988): Numerically stable algorithm for discrete-ordinate-method radiative transfer in multiple scattering and emitting layered media, Appl. Opt., 27, 2502-2509.

TEVINI, M. (1993): Effects of enhanced UV-B radiation on terrestrial plants, in $U V-B$ Radiation and Ozone Depletion: Effects on Humans, Animals, Plants, Microorganisms, and Materials, edited by M. TEVINI (Lewis Publishers, Boca Raton, Florida), 125-153.

TwOMEY, S. (1977): The influence of pollution on the shortwave albedo of clouds, J. Atmos. Sci., 34, 11491152.

Zerefos, C.S., A.F. BAIS, C. Meleti and I.C. Ziomas (1995): A note on the recent increase of solar UV-B radiation over northern middle latitudes, Geophys. Res. Lett., 22, 1245-1247. 